\title{
Pengenalan Game Edukasi Android Sebagai Penunjang Perkembangan Kognitif Anak
}

\author{
Ela Suryani $^{1}$, Kartika Yuni Purwanti ${ }^{2}$ \\ ${ }^{1,2}$ Program Studi Pendidikan Guru Sekolah Dasar, Universitas Ngudi Waluyo \\ Email: ela.suyani16@gmail.com ${ }^{1}$, kartika.yuni92@gmail.com ${ }^{2}$
}

\begin{abstract}
ABSTRAK
Kegiatan pengabdian kepada masyarakat dilakukan di PKK Desa Payungan Kecamatan Kaliwungu Kabupaten Semarang dalam rangka membantu orangtua memahami game edukasi android yang layak dikonsumsi anak. Game edukasi sebagai penunjang perkembangan kognitif anak sehingga orangtua harus memahami berbagai macam jenis aplikasi game edukasi, cara memilih game edukasi yang tepat, dan cara menginstal di handphone. Metode pelaksanaan yang digunakan adalah presentasi, demonstrasi, praktik, brainstorming, dan sharing tentang game edukasi kepada kader PKK Desa Payungan. Kegiatan ini dilakukan melalui tiga tahap yaitu 1) sosialisasi, 2) pendampingan, 3) monitoring dan evaluasi. Hasil dari pelaksanaan kegiatan ini adalah: 1) pemahaman mengenai game edukasi android sebagai penunjang perkembangan kognitif anak dalam kategori sangat baik. Hal ini ditandai dengan persentase indikator ketercapaian mengenal game edukasi (96\%), memilih game edukasi (89\%), menginstal game edukasi (93\%), dan mengimplementasikan game edukasi $(86 \%)$; 2) memperoleh respon positif yang dilihat dari indikator kehadiran peserta mencapai $93 \%$ dari target dan peserta antusias selama mengikuti kegiatan dari awal sampai akhir kegiatan. Tujuan akhir dari pengenalan game edukasi adalah orangtua melek IT sehingga mampu memantau anaknya dalam menggunakan handphone khususnya ketika bermain game.
\end{abstract}

Kata kunci: game edukasi, perkembangan kognitif

\section{ABTRACT}

Community service activities performed in PKK Payungan Village, Kaliwungu District Semarang Regency help to parents understand educational games android decent child consumed. Educational games to support cognitive development of children so that parents must understand the various types of educational game applications, how to choose the right educational game, and how to install on the phone The implementation method used was presentation, demonstration, practice, brainstorming, and sharing about educational game to PKK Payungan Village. This activity is done through three stages: 1) socialization, 2) mentoring, 3) monitoring and evaluation.

The results of the implementation of this activity was: 1) understanding educational games android as supporting the cognitive development of children in very good category. This is indicated by the percentage of achievement indicators of educational games (96\%), choosing educational games (89\%), installing educational games (93\%), and implementing educational games (86\%); 2) get positive response seen from indicator attendance reaches $93 \%$ of target and enthusiastic participant during activity from beginning to end of activity. The final goal of the introduction of educational games was IT literacy parent so as to be able to monitor their children in using mobile phones especially when playing games.

Key words: educational game, cognitive development 
Ela Suryani' ${ }^{1}$, Kartika Yuni Purwanti ${ }^{2}$ /Aksiologiya: Jurnal Pengabdian Kepada Masyarakat. Vol.3, No.2, Agustus 2019 Hal 148 - 156

\section{PENDAHULUAN}

Di Indonesia banyak orang yang menggunakan handphone android dari anak-anak hingga orangtua. Mayoritas pengguna android digunakan untuk bermain game seperti yang dilaporkan MoboMarket menunjukkan bahwa aplikasi game merupakan aplikasi yang paling banyak diunduh pengguna android. Hal ini terlihat dari survey Arif (2015) dalam Tribun News bahwa jumlah persentase pengunduh game sebanyak $43 \%$, media sosial sebanyak $12 \%$ dan aplikasi foto sebanyak $11 \%$.Data serupa juga menunjukkan hal yang sama bahwa Indonesia memiliki jumlah persentase pemasangan aplikasi game yang tinggi berdasarkan data Unity Technologies bahwa Indonesia menempati posisi paling tinggi hingga tiga kali lipat dari hasil survei di tiga negara lain seperti Amerika Serikat, Meksiko, dan India. Oleh karena itu, perlu adanya bimbingan dalam menggunakan android bagi semua kalangan masyarakat supaya terarah kebermanfaatannya.

Saat ini, anak-anak memiliki porsi yang besar sebagai pengguna teknologi digital dan diprediksikan akan meningkat secara signifikan pada tahun-tahun mendatang. Hal ini dipengaruhi oleh kemampuan adaptasi anak yang baik terhadap teknologi. Anak-anak mampu berinteraksi dengan mengikuti perkembangan teknologi digital seperti internet, video games, dan computer games (Selwyn, 2009).
Anak sebagai pengguna aplikasi memiliki karakteristik yang berbeda dengan orang dewasa. Anak memiliki kemampuan kognitif dan komunikasi yang masih terbatas dan belum berkembang sempurna. Anak-anak akan menggunakan aplikasi di handphone jika aplikasi tersebut menarik, disukai dan sesuai dengan kemampuan yang dimilikinya.

Anak usia sekolah paling suka menggunakan game yang ada di handphone android. Akan tetapi, ketertarikan anak-anak terhadap teknologi digital tidak diimbangai dengan pemahaman orangtuanya. Orangtua tidak paham mengenai game yang layak digunakan anaknya. Orangtua juga tidak pernah memeriksa game yang dikonsumsi anaknya seperti yang dialami oleh masyarakat di Desa Payungan Kecamatan Kaliwungu Kabupaten Semarang. Kondisi orangtua yang cuek terhadap game yang dikonsumsi anaknya karena ketidakmahiran orangtua dalam mengakses game di android dan keengganan untuk mengikuti kemajuan teknologi terkait game edukasi yang menunjang perkembangan anak.

Dari analisis situasi masyarakat Desa Payungan yang berjumlah 36 orang terlihat bahwa hanya $4 \%$ yang mengenal game edukasi, tidak ada yang dapat memilih game yang termasuk game edukasi, $11 \%$ yang mampu menginstal game, dan belum ada yang menggunakan game edukasi untuk anaknya. Hal ini tidak sebanding dengan handphone yang telah 
digunakan oleh para orangtua di PPK

Desa Payungan yang telah berbasis android.

Penyebab dari ketidakoptimalan memanfaatkan game di android dikarenakan minimnya tingkat pemahaman game edukasi yang dimiliki oleh orangtua di Desa Payungan. Sebenarnya game dapat memiliki dampak positif terhadap perkembangan anak jika digunakan dengan benar dan mengikuti peraturan yang telah ditetapkan oleh orang tua terkait waktu penggunaan dan konten atau permainan yang dapat diakses anak menggunakan teknologi.

Oleh karena itu perlu adanya pengenalan game edukasi bagi masyarakat Desa Payungan Kecamatan Kaliwungu supaya penggunaan game anak lebih terarah. Tidak hanya anak sebagai konsumen, orang tua juga perlu diedukasi tentang game edukasi yang dapat menunjang perkembangan kognitif anak. Peran penting dalam mengawasi perkembangan anak ada di tangan orang tua. Jadi orang tualah yang menjadi titik awal pengawasan karena anak berkembang dimulai dari rumah.

Dengan demikian kegiatan program pengabdian ini ditujukan kepada orangtua untuk mengenalkan berbagai macam game edukasi sebagai penunjang perkembangan kognitif anaknya, mendampingi para orangtua dalam memililh dan menggunakan game edukasi android, dan menganalisis tanggapan para orangtua terhadap penggunaan game edukasi android bagi anak.

\section{METODE KEGIATAN}

Sasaran kegiatan pengabdian kepada masyarakat adalah kader PKK Desa Payungan yang berjumlah 29 orang. Metode kegiatan yang dilakukan dalam pengabdian masyarakat ini adalah dengan metode partisipatif artinya mitra binaan secara aktif dilibatkan dalam semua tahapan kegiatan pengabdian masyakat ini.

Metode tersebut meliputi presentasi menggunakan powepoint, ceramah, demonstrasi, praktik, branstorming, dan sharing. Game edukasi yang dipaparkan kepada kader PKK Desa Payungan difokuskan untuk melatih anak untuk mengenal angka dan huruf, melatih anak untuk membuat kata sederhana, mengenalkan anak dengan lingkungan sekitar, melatih konsentrasi dan daya ingat, meningkatkan kemampuan penyelesaian masalah, melatih strategi, merangsang otak kanan, meningkatkan semangat kompetitif, dan dapat menjadi alternatif mengisi waktu luang dengan bermain sambil belajar.

Kegiatan pengabdian masyarakat ini meliputi tiga kegiatan sebagai berikut.

1. Sosialisasi melalui presentasi menggunakan powepoint, ceramah, demonstrasi, branstorming, dan sharing untuk mengenalkan game edukasi kepada masyarakat di PKK Desa Payungan meliputi dampak penggunaan game di handphone (keuntungan dan kerugian), jenis game di handphone android, 
game yang berbahaya bagi anak, game edukasi yang layak dikonsumsi anak, kegunaan game edukasi bagi perkembangan kognitif anak.

2. Penerapan berupa pendampingan memilih game edukasi yang menunjang perkembangan kognitif anak meliputi: cara searching game edukasi, menginstal game edukasi di playstore, dan cara menggunakan game edukasi.

3. Monitoring dan evaluasi yaitu kegiatan yang mem-follow up dari kedua kegiatan di atas sehingga pelaksana menemukan temuantemuan yang dapat digunakan sebagai bahan pertimbangan/ perbaikan ketika melaksanakan kegiatan pengabdian.

Tingkat keberhasilan program ini dilakukan melalui pengamatan langsung melalui penilaian kinerja dan kemampuan peserta dalam proses memahami berbagai game edukasi android, cara memiih game edukasi android yang sesuai perkembangan kognitif anaknya, men-download dan menginstal aplikasi game edukasi android, dan mengiplementasikannya kepada anak dengan mengacu pada indikator yang tercantum dalam rubrik. Kegiatan pengabdian dikatakan berhasil apabila tiap kemampuan mencapai persentase $\geq 75 \%$.

\section{HASIL DAN PEMBAHASAN}

Pertama, kegiatan sosialisasi pengenalan berbagai macam game edukasi android dengan jumlah peserta 27 orang (93\%). Kegiatan ini dilakukan oleh 2 orang tim pelaksana dengan pokok bahasan yang disampaikan adalah sebagai berikut.

1. Gambaran umum game edukasi

2. Dampak penggunaan game di handphone (keuntungan dan kerugian)

3. Jenis game di handphone android

4. Game yang berbahaya bagi anak

5. Game edukasi yang layak dikonsumsi anak

6. Kegunaan game edukasi bagi perkembangan kognitif anak.

7. Cara memilih game edukasi android yang sesuai dengan perkembangan kognitif anaknya (mempertimbangkan scoop dan rating game di playstore).

Kegiatan ini diawali dengan presentasi berupa ceramah yang dilanjutkan brainstorming dan sharing sehingga ditemukan $89 \%$ ibuibu banyak yang belum mengetahui game edukasi. Peserta kegiatan beranggapan semua game yang dimainkan oleh anaknya di handphone hanya digunakan untuk hiburan saja tanpa ada nilai edukasi yang dapat disisipkan.

Setelah mengikuti kegiatan sosialiasasi, kader PKK Desa Payungan telah mengetahui bahwa terdapat game di hanphone android yaitu game edukasi yang dapat digunakan sebagai media belajar sebagai penunjang perkembangan kognitif anaknya. Game edukasi merupakan permainan yang mengandung unsur belajar dan memanfaatkan kecanggihan handphone android. Sejalan dengan 
penelitian yang dilakukan Delima, dkk (2015) bahwa terdapat 94\% anak yang menggunakan perangkat teknologi untuk bermain game. Anak lebih suka belajar yang mengandung unsur permainan. Melalui permainan, anak dapat belajar banyak hal karena dengan bermain anak-anak merasa senang dan mampu berkonsentrasi lebih lama sehingga kemampuan mengingatnya menjadi lebih baik. Oleh karena itu, orangtua tidak boleh melarang anak bermain game akan tetapi harus diarahkan ke game edukasi yang menunjang perkembangan kognitif anak.

Apabila orangtua tidak mengetahui perkembangan teknologi di era digital sangat disayangkan karena teknologi merupakan sebuah tool yang dapat memberikan dampak positif atau negatif bagi anak tergantung penggunaannya. Peran orangtua menjadi sangat penting sebagai elemen yang mengendalikan pemanfaatan teknologi (Gutnict, et al, 2010). Dengan adanya kegiatan pengabdian ini yang mengubah mindset kader PKK Desa Payungan untuk melek IT sehingga memiliki pemahaman game edukasi yang dapat menunjang perkembangan kognitif anak.

Kedua, kegiatan penerapan berupa pendampingan dengan peserta berjumlah 29 orang (100\%). Kader PKK Desa Payungan melakukan praktik langsung dalam memilih game edukasi yang menunjang perkembangan kognitif anak meliputi cara searching game edukasi, menginstal game edukasi di playstore, dan cara menggunakan game edukasi.

Kegiatan ini dilakukan secara berkelompok. Artinya peserta kegiatan yang hadir dikelompokkan menjadi 3 kelompok berdasarkan jenjang pendidikan anaknya yaitu 1) PAUD/PGRA/TK/bayi; 2) SD/MI/ seusianya; 3) SMP/MTs/ seusianya; 4) SMA/MA/SMK/ seusianya. Hal ini dimaksudkan supaya tim pelaksana mudah dalam memberikan arahan dan mengklasifikasikan game edukasi yang sesuai perkembangan kognitif anak.

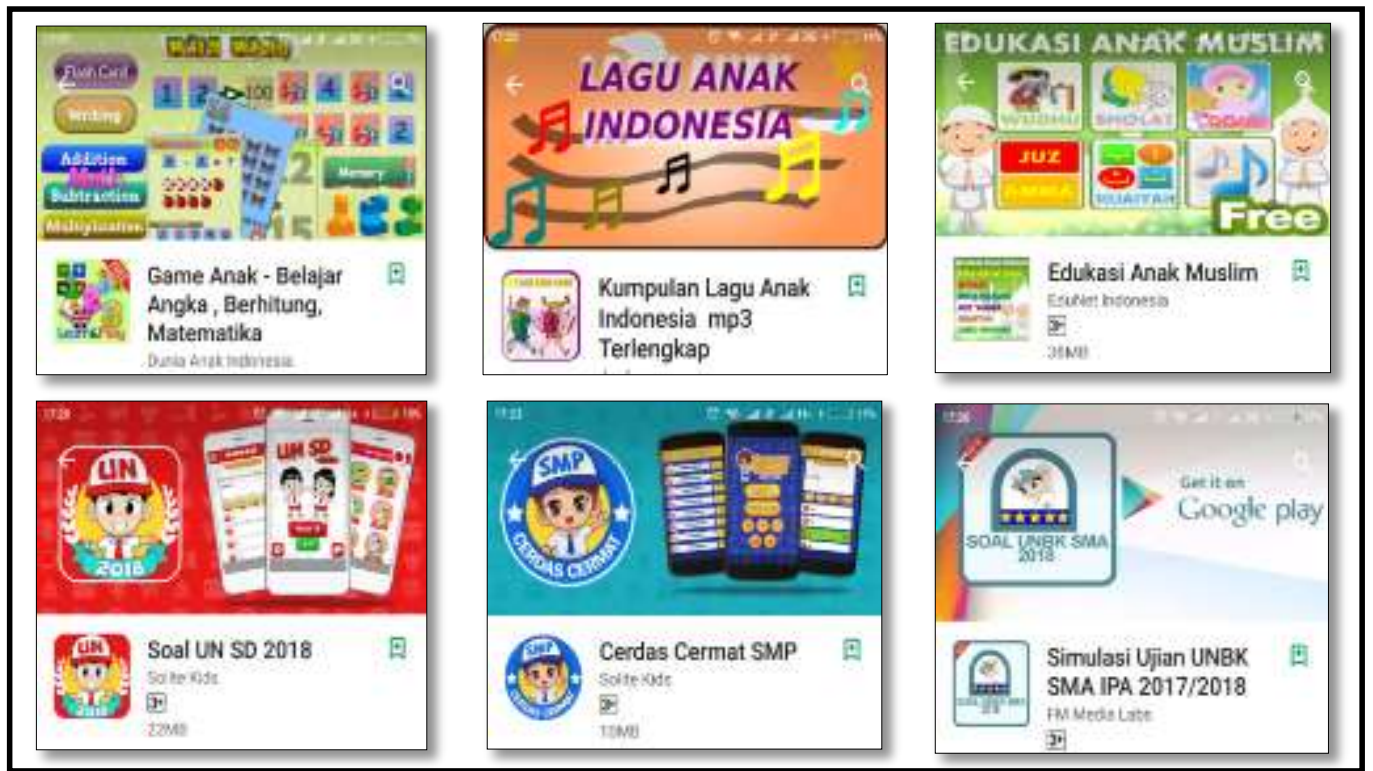

Gambar 1 Contoh game edukasi 
Peserta kegiatan sudah mengetahui cara menginstal game android dari playstore sebanyak $11 \%$ namun belum memahami game yang diinstal termasuk game edukasi yang layak digunakan anaknya atau tidak. Oleh karena itu, selama kegiatan kedua ini peserta diminta praktik langsung searching game edukasi sendiri namun tetap dibimbing tim pelaksana. Mayoritas peserta belum memperhatikan rating game edukasi yang dipilih sehingga tim pelaksana selalu memberikan arahan dan meminta peserta menunjukkan game edukasi yang dipilihnya sebelum diinstal di handphone.

Ketiga, kegiatan monitoring dan evaluasi (monev) dalam rangka mem-follow up dari kedua kegiatan yang telah dilakukan sebelumnya sehingga pelaksana menemukan temuan-temuan yang dapat digunakan sebagai bahan pertimbangan/ perbaikan ketika melaksanakan kegiatan pengabdian kepada masyarakat.

Hasil ketiga kegiatan yang telah dilakukan menunjukkan peningkatan pemahaman yang dimiliki peserta kegiatan yang berjumlah 29 orang. Peningkatan tersebut dapat terlihat pada persentase pemahaman sebelum dilakukannya kegiatan pengabdian kepada masyarakat dan setelah dilakukannya kegiatan pengabian kepada masyarakat yang dapat terlihat pada Gambar 1.

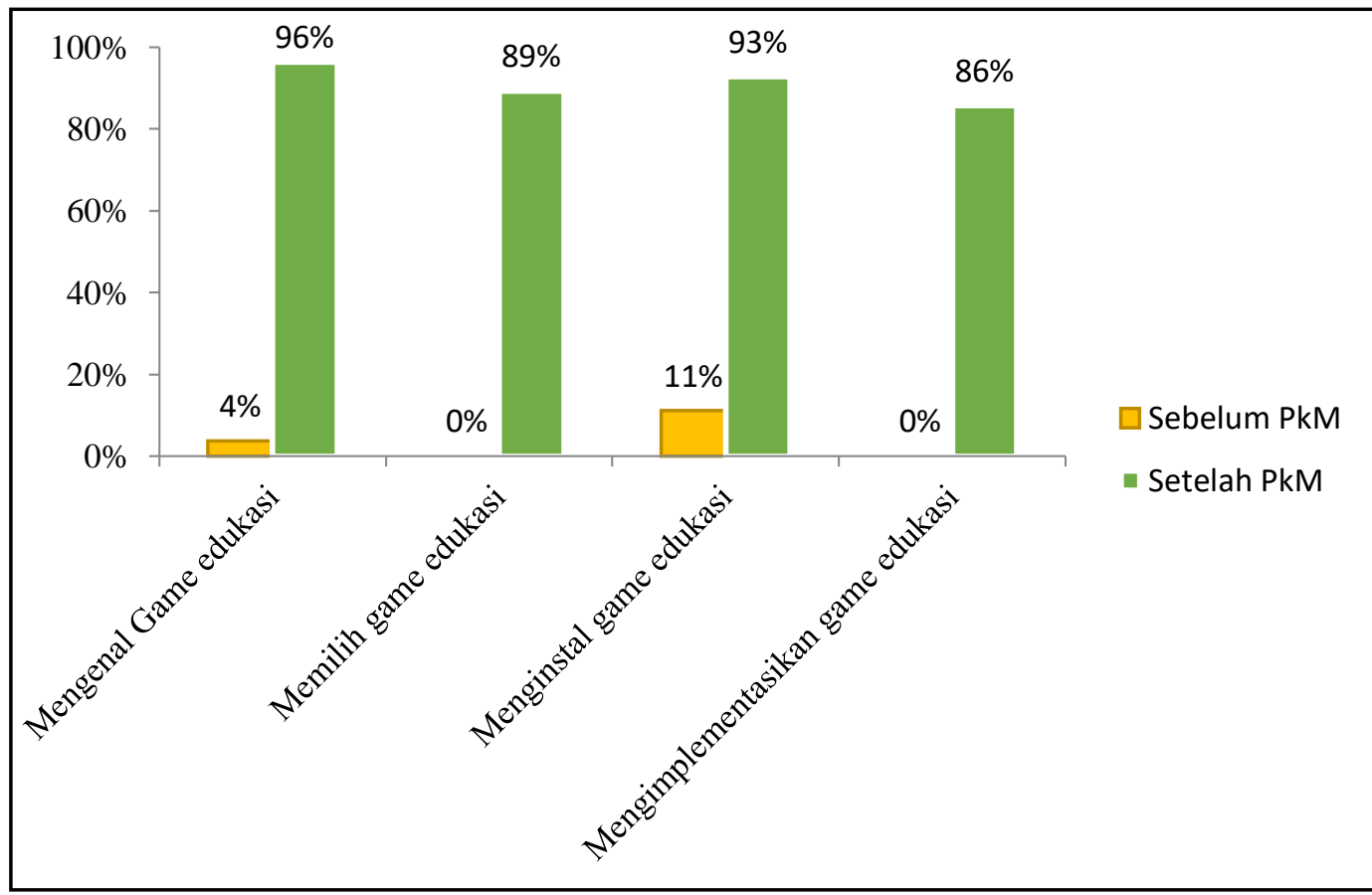

Gambar 2 Peningkatan pemahaman game edukasi android setelah PkM

Berdasarkan Gambar 2, kader

PKK Desa Payungan mengalami peningkatan pemahaman game edukasi android terkait macam- 
macam game android yang sesuai dengan perkembangan anaknya sebesar 92\%, cara memilih game edukasi sebesar $89 \%$, menginstal game edukasi android di handphone sebesar $82 \%$, dan mengimplementasi kan game edukasi bagi anaknya sebesar $86 \%$. Oleh karena itu, hasil kegiatan pengenalan game edukasi android sebagai penunjang perkembangan kognitif anak di PKK Desa Payungan dapat dikatakan berhasil dalam kategori sangat baik. Hasil kegiatan ini diharapkan dapat digunakan para orangtua di Desa Payungan dalam membimbing dan memantau game yang dikonsumsi oleh anak sesuai perkembangan kognitif anaknya.

Kegiatan pengabdian kepada masyarakat yang telah dilakukan tim pelaksana mendapat respon positif dari para kader PKK Desa Payungan yang terlihat dari peserta antusias mengikuti kegiatan dan hasil kegitan juga dalam kategori sangat baik. Sebelum adanya kegiatan pengabdian ini, orangtua yang tergabung dalam PKK Desa Payungan belum mengenal game edukasi android padahal mayoritas anak-anaknya sudah menggunakan handphone android dan memasang game di handphone miliknya.

Ketepatan memililh game edukasi yang telah dikuasai kader PKK Desa Payungan juga meningkat (seperti yang terlihat pada Gambar 2). Peserta sudah memperhatikan scoop dan rating aplikasi game edukasi yang akan diinstal. Selain itu juga mempertimbangkan jenjang pendidikan anaknya dan perkembangan kognitif anaknya supaya tepat ketika digunakan. Anak sebagai pengguna aplikasi memiliki karakteristik yang berbeda dengan orang dewasa. Anak memiliki kemampuan kognitif dan komunikasi yang masih terbatas dan belum berkembang sempurna.

Oleh karena itu, kemampuan kognitif awal anak akan mempengaruhi perkembangan kognitif selanjutnya. Seperti penelitian yang telah dilakukan Suryani, et al (2016) bahwa kemampuan kognitif akan berkembang apabila anak termotivasi menemukan konsep yang tepat karena terdapat ketidaksesuaian antara konsepsi awal yang dimilikinya. Konsep awal anak inilah yang dapat berasal dari pengalaman yang berasal dari aplikasi handphone. Anak akan menggunakan aplikasi jika aplikasi tersebut menarik, disukai dan sesuai dengan kemampuan yang dimiliki anak sehingga kader PKK Desa Payungan selaku orangtua dibekali pemahaman game edukasi yang sesuai jenjang pendidikan anak pada saat kegiatan pendampingan.

Penelitian di Jepang diketahui bahwa kemampuan adaptasi anak terhadap teknologi lebih tinggi dan lebih natural dibandingkan dengan buku teks. Hal ini menunjukan bahwa menggunakan teknologi informasi pada pendidikan membuat pengalaman belajar menjadi lebih efektif dan lebih menyenangkan (Naeyc, 2012). Hal ini sejalan dengan tujuan akhir kegiatan pengabdian 
Ela Suryani ${ }^{1}$, Kartika Yuni Purwanti ${ }^{2}$ Aksiologiya: Jurnal Pengabdian Kepada Masyarakat. Vol.3, No.2, Agustus 2019 Hal 148 - 156

masyarakat ini adalah game edukasi android dapat digunakan sebagai penunjang perkembangan kognitif anak yang didukung oleh kemampuan orangtua dalam menggunakan game edukasi android.

\section{SIMPULAN}

Kegiatan pengabdian kepada masyakarat yang diberikan kepada kader PKK Desa Payung dapat disimpulkan sebagai berikut.

1. Pemahaman mengenai game edukasi android sebagai penunjang perkembangan kognitif anak dalam kategori sangat baik. Hal ini ditandai dengan persentase indikator ketercapaian mengenal game edukasi (96\%), memilih game edukasi (89\%), menginstal game edukasi (93\%), dan mengimplementasikan game edukasi (86\%).

2. Memperoleh respon positif yang dilihat dari indikator kehadiran peserta mencapai $93 \%$ dari target dan peserta antusias selama mengikuti kegiatan dari awal sampai akhir kegiatan.

Kegiatan yang mengenalkan game edukasi android respon yang positif. Akan tetapi, hal ini dapat ditindaklanjuti oleh kader untuk dibagikan kepada masyarakat di dusunnya masing-masing supaya ibuibu yang lain juga memahami game edukasi android yang sesuai dengan perkembangan kognitif anaknya dan mampu memberikan arahan kepada anak mengenai game yang sekaligus digunakan untuk belajar.

\section{DAFTAR PUSTAKA}

Arief. 2015. "Aplikasi Game Paling Sering Diunduh Pengguna Smartphone di Indonesia". Tribun News Pontianak, 17 Januari 2015. Delima, R., Arianti, N., K., Pramudyawardani, B. 2015. "Identifikasi Kebutuhan Penggunaan untuk Aplikasi Permainan Edukasi bagi Anak Usia 4 sampai 6 Tahun". Jurnal Teknik Informatika dan Sistem Informasi. 1(1): 42-47

Gutnict., A.L., Robb., M., L. Takeuchi, Kitler, J. 2010. Always Connected: The New Digital Media Habits of Young Children. The Joan Ganz Cooney Center at Sesame Warkshop : New York Maisyara, I., Kasih, F., Nita, W., R. "Peran Orang Tua Dalam Membantu Pencapaian Perkembangan Kognitif Anak Sekolah Dasar Di Kelurahan Siguhung Kecamatan Lubuk Basung Kabupaten Agam". STIKIP PGRI Sumatera Barat: Sumatera Barat

Maulana, R. 2017. "Tingkat Perkembangan Pasar Game Mobile Indonesia Tiga Kali Lipat Amerika Serikat". Techinasia, 27 Februari 2017.

Https://Id.Techinasia.Com/Perke mbangan-Pasar-Game-IndonesiaSalah-Satu-Yang-Tertinggi-Di$\underline{2016}$

Naeyc, Fred Rogers Center. 2012. Technology and Interactive Media as Tools in Early Childhood Programs Serving Children from Birth Through Age 
Ela Suryani ${ }^{1}$, Kartika Yuni Purwanti ${ }^{2}$ /Aksiologiya: Jurnal Pengabdian Kepada Masyarakat. Vol.3, No.2, Agustus 2019 Hal 148 - 156

8, A joint Position Statement. [online]

www.naeyc.org/files/naeyc/file/p ositions/PS_technology_WEB2.p df

Selwyn, N. 2009. "The Digital Native-Myth and Reality". Aslib Proceedings: New Information Perspectives. 61(4): 364-379
Suryani, E. Rusilowati, A., \& Wardono. 2016. "Analisis Pemahaman Konsep IPA Siswa SD Menggunakan Two-Tier Test melalui Pembelajaran Konflik Kognitif". Journal of Primary Education. 5(1): 56-65 